\title{
The Drosophila spitz gene encodes a putative EGF-like growth factor involved in dorsal-ventral axis formation and neurogenesis
}

\author{
Barbara J. Rutledge, ${ }^{1,3,4}$ Kang Zhang, ${ }^{1,3,5}$ Ethan Bier, ${ }^{2,6}$ Yuh Nung Jan, ${ }^{2}$ and Norbert Perrimon ${ }^{1}$ \\ ${ }^{1}$ Department of Genetics, Howard Hughes Medical Institute, Harvard Medical School, Boston, Massachusetts 02115 USA; \\ ${ }^{2}$ Department of Physiology and Biochemistry, Howard Hughes Medical Institute, University of California, San Francisco, \\ California 94143 USA
}

\begin{abstract}
We describe the molecular characterization of the Drosophila gene spitz (spi), which encodes a putative 26-kD, EGF-like transmembrane protein that is structurally similar to TGF- $\alpha$. Temporal and spatial expression patterns of spi transcripts indicate that spi is expressed throughout the embryo. Examination of mutant embryos reveals that spi is involved in a number of unrelated developmental choices, for example, dorsal-ventral axis formation, glial migration, sensory organ determination, and muscle development. We propose that spi may act as a ligand for cell-specific receptors, possibly rhomboid and/or the Drosophila EGF receptor homolog.
\end{abstract}

[Key Words: Drosophila; epidermal growth factor; dorsal-ventral axis; neurogenesis; CNS; PNS]

Received March 16, 1992; revised version accepted April 28, 1992

Positional information along the dorsal-ventral embryonic axis in the Drosophila embryo appears to be defined by the protein encoded by the dorsal gene (Steward 1987). At the syncytial blastoderm stage a gradient of nuclear localized dorsal protein is established in response to the activity of a set of maternally expressed genes (Stein et al. 1991). This dorsal gradient causes zygotically acting genes to become activated. Expression patterns of specific genes suggest that the Drosophila embryonic ectoderm might be subdivided into a series of longitudinal stripes. For example, the expression of the twist and snail genes (Leptin and Grunewald 1990) is restricted to ventral-longitudinal domains; the expression of single-minded (Crews et al. 1988; Thomas et al. 1988) and rhomboid (rho) (Bier et al. 1990) is restricted to a ventrolateral domain; and the expression of zerknüllt (Doyle et al. 1986) and decapentaplegic $\langle d p p\rangle$ (St. Johnston and Gelbart 1987) is restricted to dorsal territories. In ventrolateral regions, subdivision of the ectoderm may depend on the action of Star $(S)$, spitz (spi), rho, and pointed (pnt), members of the spitz group

\footnotetext{
${ }^{3}$ These authors contributed approximately the same amount to this work.

Present addresses: ${ }^{4}$ Department of Medicine, Dana-Farber Cancer Institute, Boston, Massachusetts 02115 USA; ${ }^{5}$ Harvard University-Massachusetts Institute of Technology, Division of Health Sciences and Technology, Harvard Medical School, Boston, Massachusetts 02115 USA. ${ }^{6}$ Department of Biology, University of California at San Diego, La Jolla, California 92093 USA.
}

(Mayer and Nüsslein-Volhard 1988). Mutations in the spitz group genes perturb the fate of structures derived from the blastoderm region located dorsally to the mesectoderm.

In addition to their role in dorsal-ventral axis formation, some members of the spitz group genes are involved in other developmental pathways, such as sensory organ specification and glial migration. Embryos mutant for rho, spi, $S$, or pnt lack two of the five lateral chordotonal organs in the peripheral nervous system (PNS) (Jan et al. 1986; Bier et al. 1990). Additionally, in the central nervous system (CNS) of rho, spi, and $S$ mutant embryos, the anterior and posterior commissures are fused, possibly owing to the failure of some glial cells to migrate (Klämbt et al. 1991).

In this paper we present the molecular and phenotypic description of spi. We show that spi encodes a protein that is structurally similar to a factor that is epidermal growth factor (EGF)-like. On the basis of protein structures, comparison of phenotypes, and spatial and temporal expression patterns, we propose that spi encodes a ligand that functionally interacts with the products of the rho and, possibly, Drosophila EGF receptor (DER) genes.

Results

Genetics of the spi locus

spi maps to cytological position $37 \mathrm{~F}-38 \mathrm{~A}$, a genetically 
Figure 1. Cloning of the spi gene. $(A)$ Genetic map of the spi region. Deficiency chromosomes are shown by horizontal lines. Arrows show that deficiencies extend distally or proximally. The locations of the $D d c$ gene and the genes immediately adjacent to spi are indicated above the lines (see also Gilbert et al. 1984; Contamine et al. 1989). The spi locus maps proximal to the ref(2)P locus, which confers resistance to sigma virus, and distal to the lethal complementation group 1(2)E42. The spi locus is linked very tightly to another lethal complementation group, 1(2)E146; the relative map order of these two loci has not been determined. (B) Cloning strategy and localization of deficiency breakpoints. The spi region was cloned both by chromosomal walking, by use of a subclone from the $D d c$ phage walk to "jump" into the DNA proximal to the Df(2L)VA17 deficiency, and by P-element rescue. Plasmid p1022 (Gilbert et al. 1984) was used to isolate a "junction" fragment from a library made from $D f(2 L) V A 17 / C y O$ flies. A phage walk with Oregon- $R$ DNA was initiated in both directions, and the approximate alignment of the phage is shown here. Identification of the spi-containing phage was confirmed by localization of two P-element insertions, $s p i^{G R 883}$ and $s p i^{I D B 7}$, in phage $\mathrm{R}_{37}$, and by P-element "rescue" of $s p i^{I D B 7}$ and isolation of phage hybridizing to genomic DNA flanking the P-element insertion. The broken line interrupting $D f(2 L) V A 17$ indicates that the deficiency is not drawn to scale.

well-characterized region of the second chromosome. The location of spi respective to overlapping deficiencies from that region is shown in Figure 1A, and the stocks used in this study are summarized in Table 1 (see Materials and methods). We have characterized eight alleles at the spi locus. Nüsslein-Volhard et al. (1984) originally characterized two alleles, and we found spi to be allelic to the previously identified 1(2)OE92 locus (Contamine et al. 1989), which includes three alleles. The chromosome containing the pupal-lethal $d p p$ allele $d p p^{13}$ (Lindsley and Zimm 1985) is an inversion chromosome also mutant for spi. Finally, there are two spi mutations that

Table 1. Strains mutant for spi

\begin{tabular}{|c|c|c|}
\hline Rearrangements & Cytology ${ }^{a}$ & References \\
\hline$D f(2 L) V A 17$ & $37 \mathrm{C} 1,2-37 \mathrm{~F} 5$ & Wright et al. (1981) \\
\hline$D f(2 L) E 55$ & $37 \mathrm{D} 2-\mathrm{E} 1 ; 37 \mathrm{~F} 5-38 \mathrm{~A} 1$ & Wright et al. (1976) \\
\hline$D f(2 L) T W 9$ & $37 \mathrm{~B} 2-8 ; 37 \mathrm{E} 2-\mathrm{F} 4$ & Wright et al. (1976) \\
\hline$D f(2 L) T W 84$ & 37F5-38A1; 39D3-E1 & Wright et al. (1976) \\
\hline$D f(2 L) T W 158$ & $37 \mathrm{~B} 2-8 ; 37 \mathrm{E} 2-\mathrm{F} 4$ & Wright et al. (1976) \\
\hline$D f(2 L) O D 12$ & ND & Contamine et al. (1989) \\
\hline$D f(2 L) O D 21$ & ND & D. Contamine (pers. comm.) \\
\hline$s p i^{d p p 13}$ & $\begin{array}{l}\mathrm{Tp}(2) 22 \mathrm{~F} 1-2 ; 24 \mathrm{C} 1-2 ; \\
\quad 37 \mathrm{~F} ; 40\end{array}$ & Lindsley and Zimm $(1985)$ \\
\hline spitz alleles & origin $^{a}$ & \\
\hline$s p i^{I I A 14}$ & EMS & Nüsslein-Volhard et al. (1984) \\
\hline spi ${ }^{\text {IIT25 }}$ & EMS & Nüsslein-Volhard et al. (1984) \\
\hline Spi ${ }^{\mathrm{OE} 92}$ & EMS & Contamine et al. (1989) \\
\hline$s p i^{G R 883}$ & $\begin{array}{l}\text { P-element } \\
\text { transformation }\end{array}$ & Karess and Rubin (1984) \\
\hline$s p i^{I D B 7}$ & hybrid dysgenesis & Bier et al. (1989) \\
\hline$s p i^{d p p 13}$ & $X$-ray & Lindsley and Zimm (1985) \\
\hline spi ${ }^{O D 7}$ & diepoxybutane & Lindsley and Zimm (1986) \\
\hline$s p i^{O D 24}$ & diepoxybutane & Lindsley and Zimm (1986) \\
\hline
\end{tabular}

a(ND) Not determined; (EMS) ethylmethane sulfonate. 
are associated with P-element insertions (Karess and $\mathrm{Ru}$ bin 1984; Bier et al. 1989). All of the spi alleles isolated to date are embryonic lethal alleles.

\section{Cloning of the spi region and identification of the spi gene}

The spi region was cloned using a twofold approach. Initially, a clone from the dopa-decarboxylase $(D d c)$ region at $37 \mathrm{Cl}, 2$ was used to cross the $D f(2 L) V A 17$ breakpoints and initiate a $70-\mathrm{kb}$ phage walk in the $37 \mathrm{~F}$ region (Fig. 1B). An EcoRI restriction fragment from the proximal region of the ref(2)P phage walk (clone $31 \mathrm{E}$; Contamine et al. 1989) hybridizes to phage 5-2 (Fig. 1B, data not shown), delimiting the distal end of the spi region. Subsequently, we obtained the P-element mutation $s p i^{I D B 7}$ (Bier et al. 1989), from which we isolated geno- mic DNA flanking the P-element insertion. The genomic DNA was mapped to the phage walk to confirm the identification of the phage containing the spi locus. Southern hybridization analysis revealed that the P-element insertions in both $s p i^{I D B 7}$ and a second P-element allele, $s p i^{G R 883}$, map to a $1.3-\mathrm{kb}$ EcoRI restriction fragment in phage $R_{37}$ (Fig. 2A,B). The rearrangement allele spidpp13 shows alterations in a $2.9-\mathrm{kb} B a m H I-E c o R I$ restriction fragment $\sim 1 \mathrm{~kb}$ distal to this fragment (data not shown), indicating further that this region contains sequences essential for spi expression.

To verify that the P-element insertions in this region are responsible for the spi mutations, we attempted to revert the P-element insertions by dysgenesis, scoring for the loss of rosy ${ }^{+}\left(\mathrm{ry}^{+}\right)$(for spi $\left.{ }^{\text {GR883}}\right)$ or white ${ }^{+}\left(\mathrm{w}^{+}\right)$(for $s p i^{I D B 7}$ ) eye color. No $\mathrm{ry}^{-}$revertants of $s \mathrm{i}^{\mathrm{GR883}}$ were obtained, but $W^{-}$revertants of $s p i^{I D B 7}$ were isolated.

A.
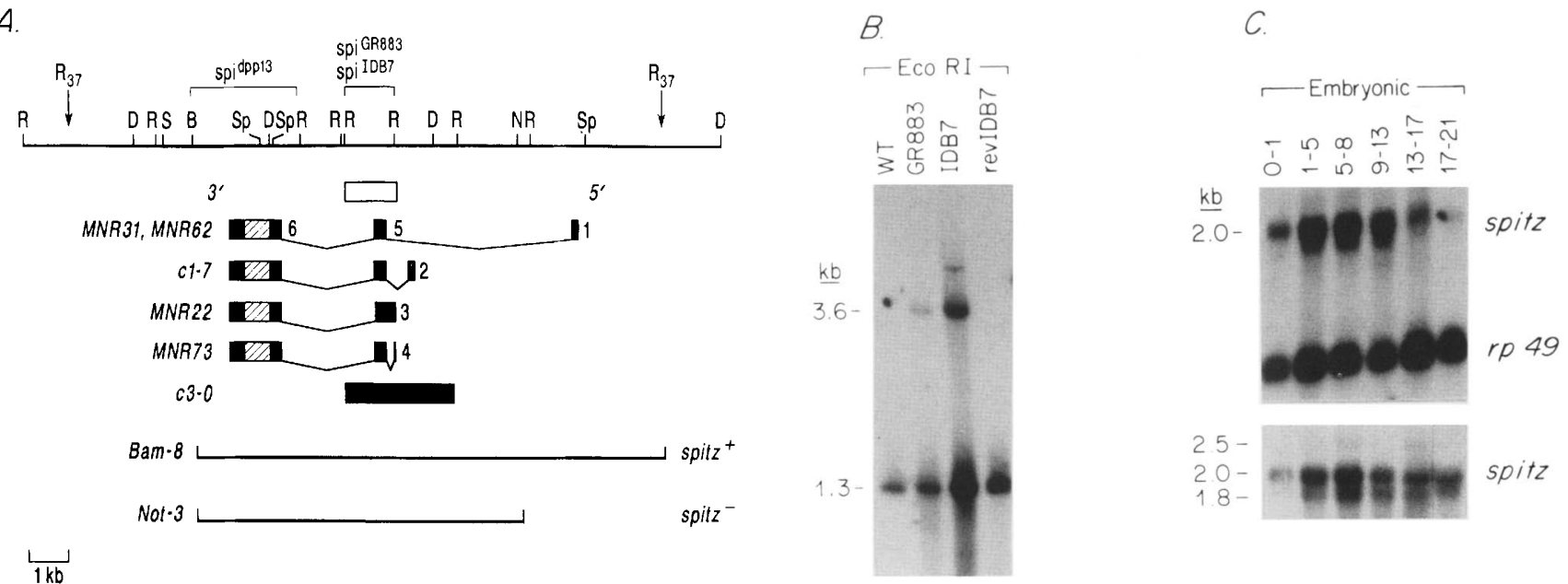

Figure 2. Molecular characterization of spi. $(A)$ Restriction map of the spi region. Genomic DNA encompassing the spi region is indicated by the top line. Arrows above the line mark the boundaries of phage $\mathrm{R}_{37}$. The $2.9-\mathrm{kb} B a m H I-E c o R I$ restriction fragment is altered in $s p i^{d p p 13}$ (data not shown). The open box below the line indicates the 1.3-kb EcoRI genomic fragment used to isolate the various spi cDNAs. This $1.3-\mathrm{kb}$ fragment is the insertion site of the two P-element-induced spi mutations $\left(s p i^{G R 883}\right.$ and $\left.s p i^{I D B 7}\right)$. The solid boxes numbered 1-6 represent the exons from cDNAs encoding the putative spi protein; the hatched region within exon 6 represents the coding sequence (see also Fig. 3). All of the cDNAs examined that encode spi are composed of two or more exons. The location of exon 1 in the genomic region has not been determined precisely, but it maps in $\mathrm{R}_{37}$ in the region proximal to the most proximal EcoRI site and distal to the SpeI site, as shown. Exon 6, containing the spi-coding region, is identical in every complete spi cDNA. Because they were all selected by hybridization to the $1.3-\mathrm{kb}$ EcoRI fragment, all of the cDNAs contain an exon from within that fragment. MNR31, MNR62, cl-7, and MNR73 all contain exon 5 from the 1.3-kb EcoRI fragment and, thus, differ only in the $5^{\prime}$-most exon. MNR22 begins at the same site as MNR73 but reads through the splice signals utilized by MNR73. The final cDNA examined, c3-0, appears to be a partial unprocessed transcript (see text); it does not contain an open reading frame, and it is entirely derived from the genomic region from which the MNR31 and MNR62 transcripts arise. Shown below the cDNAs are the fragments cloned into pCaSpeR2 (Pirrotta 1988) and used for transformation. The proximal end of the Bam-8 fragment is a BamHI site created during the construction of phage $\mathrm{R}_{37}$ and is indicated on this map by the arrow marking the proximal limit of the genomic insert in $\mathrm{R}_{37}$. The Bam-8 construct completely rescues the spi mutant phenotype, whereas the Not-3 construct fails to rescue. (B) BamHI; $(\mathrm{R})$ EcoRI; (D) HindIII; (N) NotI; (S) SalI; (Sp) SpeI. (B) Southern hybridization of P-element spi mutant and revertant strains. EcoRI digest of wild type (WT), spi ${ }^{G R 883}$, spi ${ }^{I D B 7}$, and one revertant of $s p i^{I D B 7}$ (revIDB7). The hybridization probe is the 1.3-kb EcoRI fragment. All strains except wild type are heterozygous for the second chromosome. In addition to the band corresponding to the wild-type 1.3-kb EcoRI fragment, a novel band of $\sim 3.6 \mathrm{~kb}$ is visible with the $s p i$ mutant chromosomes $s p i^{G R 883}$ and $s p i^{I D B 7}$. With the revertant strain, the novel band has disappeared, but the width of the band at $1.3 \mathrm{~kb}$ indicates that the EcoRI fragment in the revertant chromosome may be $\sim 50$ bp larger, suggesting imprecise excision. $(C)$ Northern blot hybridization with poly(A) RNA from six embryonic stages ftime periods are in hours). (Top) The upper bands show hybridization to the spi c1-7 probe; the lower bands show hybridization to the control rp49 probe. (Bottom) A similar Northern blot assay, also hybridized to the spi cl-7 probe, in which the different transcript sizes can be seen. In both cases, the probes were single-stranded RNA probes. 
Flies heterozygous for one of the revertant chromosomes and another spi allele or a spi deficiency chromosome are viable, although one or more unidentified mutations on the parental $\operatorname{spi}^{I D B 7}$ chromosome cause inviability of flies homozygous for the revertant chromosomes or heterozygous for one of the revertant chromosomes and $s p i^{I D B 7}$. Southern blot analysis revealed that the phenotypic reversion correlates with the loss of the novel restriction fragments hybridizing to the $1.3-\mathrm{kb} E c o \mathrm{RI}$ fragment in the $s p i^{I D B 7}$ chromosome (Fig. 2B).

\section{Rescue of the spi mutant phenotype by P-element transformation}

To determine the extent of the spi gene within this region, we used P-element-mediated transformation to rescue the spi mutant phenotype. Two P-element constructs were injected into Drosophila embryos. The first construct, Bam -8 , contains a $12.5 \cdot \mathrm{kb}$ BamHI restriction fragment from phage $\mathrm{R}_{37}$, including the $2.9-\mathrm{kb} E c o \mathrm{RI}-$ BamHI fragment altered in spidpp13. The second construct, Not-3, is a Bam-8 derivative without the $3-\mathrm{kb}$ NotI-BamHI fragment (Fig. 2A). Transformant flies containing a single copy of the larger of the two constructs, Bam- 8 , are viable and fertile when trans-heterozygous for two spi alleles. The smaller construct, Not-3, fails to rescue under identical conditions. These results indicate that the spi gene is contained within the $12.5-\mathrm{kb} \mathrm{BamHI}$ restriction fragment and that regions essential for spi expression lie in the region from the proximal BamHI site to the NotI site in phage $\mathrm{R}_{37}$.

\section{Isolation and characterization of spi $c D N A s$}

To isolate spi cDNAs we used as a hybridization probe the 1.3-kb EcoRI fragment altered in the two P-element insertion mutations. Twelve cDNAs from a 0- to 4-hr embryonic cDNA library (including MNR22, MNR31, MNR62, and MNR73) and two cDNAs from a 9- to 12-hr embryonic cDNA library (cl-7 and c3-0) were isolated. With one exception (c3-0), the inserts in the recombinant phage are between 1.0 and $1.7 \mathrm{~kb}$ in size. Sequencing of genomic DNA from phage $R_{37}$ and of five cDNAs with the largest inserts (MNR22, MNR31, MNR62, MNR73, and $\mathrm{c} 1-7)$ revealed that the cDNAs are composed of two or three exons and are identical except in the $5^{\prime}$ region (Figs. 2A and 3). The spi-coding region is entirely contained in exon 6. The $3^{\prime}$ ends of these cDNAs contain polyadenylation signals, and in one case the sequence ends with a poly(A) tract. Because the sizes of these cDNAs, with the addition of a poly(A) tail, are consistent with the sizes of transcripts seen on Northern blots /see below), we believe that these cDNAs represent fulllength or nearly full-length transcripts.

The remaining cDNA from the 9- to 12 -hr library, c30 , appears to be unprocessed. One end of the cDNA is 1.2 $\mathrm{kb}$ upstream from the site where $\mathrm{cl-7}$ begins, and the cDNA sequence extends $3 \mathrm{~kb}$ farther downstream with no splicing. DNA sequence analysis revealed no significant open reading frames. Because the 3-kb cDNA initiates within the first intron of the MNR31/MNR62 transcript, it could represent a partial, unprocessed transcript beginning either at the MNR31/MNR62 initiation site or at an additional initiation site that we have not yet detected. DNA sequence analysis of additional smaller cDNAs from the 0 - to 4 -hr library indicated that the smaller cDNAs are incomplete.

\section{Temporal expression of spi}

Northern analysis indicated multiple transcripts hybridizing to restriction fragments within the $12.5-\mathrm{kb}$ geno-

Figure 3. Nucleotide sequence and predicted protein sequence of spi. Lowercase letters indicate genomic sequence; uppercase letters indicate exon sequence. Numbers indicate the exons as shown in Fig. 2A. The 5 ' ends of the cDNAs were determined by sequencing EcoRI subclones from the phage; primer extension was not used to determine the precise 5 ' ends for any of the cDNAs. The exon 1 sequence shown here is from MNR62. In MNR31, exon 1 starts 35 nucleotides farther 3', probably owing to premature termination of reverse transcription during the library construction. Exon 2 is present in cDNA c1-7. All three cDNAs are spliced to exon 5 and exon 6 at the same sites. Two additional cDNAs, MNR22 and MNR73, appear to begin at the genomic EcoRI site 400 bp downstream from exon 2 (Fig. 2); the actual transcriptional start site for these cDNAs may be farther 5 '. The phage containing the cDNAs appeared to contain only a single EcoRI fragment in each case, and sequencing was performed by use of subclones from the phage. In MNR73, the first exon (exon 4) is precisely spliced to exon 5 after 33 nucleotides, before reaching the site of P-element insertion in strain $s p i^{I D B 7}$ (data not shown), at a splice junction donor site of ATG/gtacat. In MNR22 the sequence continues through the splice site, through the site of P-element insertion, and into exon 5. Both MNR22 and MNR73 are spliced from exon 5 to exon 6, with splice junctions identical to those in the other three cDNAs. In every case, the splice junction donor and acceptor sequences correlate well with the consensus sequences (Mount 1982). The putative coding region is entirely contained within exon 6 . Numbering begins with the start of translation. No sequences homologous to TATA were found in the $5^{\prime}$ region of the nucleotide sequence. In the $3^{\prime}$-untranslated region, there are four ATTTA sequences (underlined); this motif is correlated with rapid mRNA degradation and possible translational control (Shaw and Kamen 1986; Kruys et al. 1989). Shown by double underlines are the sequence AATAAA, identical to the canonical polyadenylation signal (Proudfoot and Brownlee 1976), and the dinucleotide CA, 20 nucleotides downstream, which appears to be the site where polyadenylation of the spi transcript occurs. All of the cDNAs described end at or immediately $5^{\prime}$ to this site, and in one of the cDNAs (MNR22) the dinucleotide CA is followed by a poly/A) sequence of 9 residues. Translation is shown with the single-letter amino acid code. Determination of the extent of the putative signal sequence, shown in italics, was based on the rules outlined in von Heijne (1983), with the proteolytic cleavage window occurring between proline at position 19 and serine at position 27 . The putative transmembrane domain is underlined; the extent of the transmembrane domain was based on the hydrophobicity as determined by the Kyte and Doolittle algorithm (1982). The EGF domain is indicated in boldface type, and a potential N-glycosylation site is indicated by an asterisk $\left({ }^{*}\right)$. Sequence data described here have been submitted to the EMBL/GenBank data libraries under accession number M95199. 
mic DNA used in germ-line transformation. At the distal end of the 12.5-kb genomic DNA is the 2.9-kb EcoRI$B a m H I$ fragment altered in $s p i^{d p p 13}$. This fragment includes the entire open reading frame presumed to encode the spi protein and is contained within a $3.8-\mathrm{kb} E c o \mathrm{RI}$ fragment from phage $R_{37}$, which was used as a hybridization probe. The 3.8-kb EcoRI fragment hybridized primarily to transcripts of 2.5 and $2.0 \mathrm{~kb}$, as well as to a 1.9-kb transcript (data not shown). The 1.3-kb EcoRI fragment, $\sim 1 \mathrm{~kb}$ proximal to the 3.8 -kb EcoRI fragment, also hybridized primarily to a 2 -kb transcript, as well as to a 3-kb transcript (data not shown).
In a developmental Northern blot, a spi cDNA (c1-7) detected the same pattern of transcripts as did the $3.8-\mathrm{kb}$ genomic EcoRI fragment, which includes the entire coding region (Fig. 2C). Because these hybridizations utilized single-stranded RNA probes and the same pattern was seen with both the cDNA and the $3.8-\mathrm{kb}$ genomic fragment, we assume that all of the transcripts detected are spi transcripts. A likely explanation for the multiple transcripts is that alternative splicing generates a variety of $s p i$ transcripts, differing slightly in size; this explanation is consistent with the results of cDNA analysis, which revealed variation in the $5^{\prime}$ exons of different cDNAs.

$$
\text { aagtetggcaagcacttgttcatt taagacgcgacacaacgaatTgTACTCTTTCAGTT TTTCAAAAAGAAAATGGCATGAAAACAGGCCAAAAAAGTGC }
$$$$
\text { GAGTAAGAGTGAGATGGCGAGCGAGAAAAAGAGAGCGAGAGCTGAAGCGTTGGTGGTGTGTGTGTGCGAATATGCACGTATACGCAACACACCTCAAAAG }
$$$$
\text { GTTGTTGTCTCTGCTAAATGCGCATTCTTTGGGCTCTCACGCCITTTCTGCTCTCTCCTCTCTCGATTTAAAACTTGTAGACTTGTTTCTTGAGCTTTTT }
$$$$
\text { TGCGAAAACATAAAAACCGGTAAATTTTTTTTCGAAACTGCAGGCAGAGAAAAGAGAGCGAGCTGTGTTGTTGTTCCTGTATTGGCATTTTTTACCTTAA }
$$$$
5 \longrightarrow
$$$$
\text { CCATATTTTTCACACACT'TTGCTTTCCTTACAG'T'T'TCTAAACACACACACATACAGAAACGAGAAGAGCCAACGAACTCGCAGCGACGCCCAAGAATGA }
$$$$
\text { AAGAGAGCAAGGCAACATGAAAATTACAGCAACAACAACTGGCTTGCCGAAGAAGTTGTAAAAGACGCAAGAGCAGAAGAAGAAGCAGCCACAACAGTAT }
$$$$
4,5
$$$$
\underset{g A T A C A C A C A T C A C C C C T A A C T C A A C G T T T A C G T T C C A C C A G}{ }
$$
TTTTTATTAGCGGGTGTTTTTGTTGTCATgtatgt....tettecatettccccacagATACACACATCACCCCTAACTCAACGTTTACGTTCCACCAG

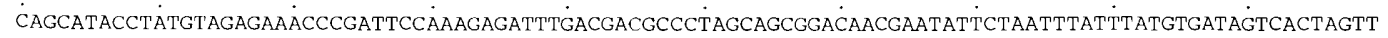
TTAATATTCTTTAAGCT TTTAÄACAACCAAAC̈GTTGCACGCCAAAAAAACGAÁCAAGCCGATÁCGCTACGCCÄAAAAGCTACÁAATTGTAATGCATTCCACA

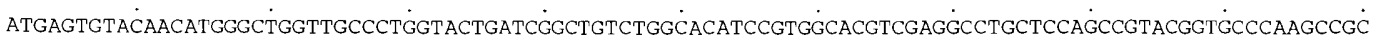
$\begin{array}{lllllllllllllllllllllllllllllllllllll}M & S & V & Q & H & G & L & V & A & L & V & L & I & G & C & L & A & H & P & W & H & V & E & A & C & S & S & \mathrm{R} & \mathrm{T} & V & \mathrm{P} & \mathrm{K} & \mathrm{P} & \mathrm{R}\end{array}$

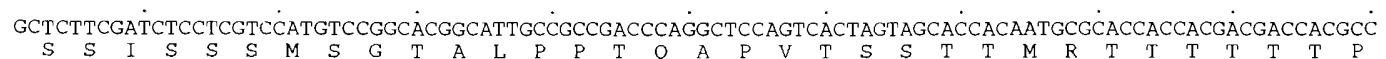
CAGGCCCAATATTACATTCCCCACATACAÄATGTCCGGAÄACCTTCGATG̈CCTGGTACTGTTTTGAACGATGCCCATTGCTTTTGCGGTGAÁGATAGCCGAT

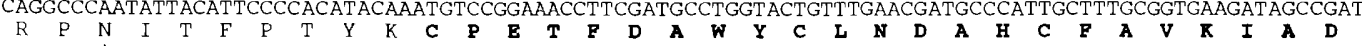
CTACCGGTTTAACAGCTGCGÄTTGGCGATTGGCTTTATGGGACAGCGATGCGAATACAAGGAGATCGACAATACTTACCTGCCCAAGAGGCCGCGTCCGA

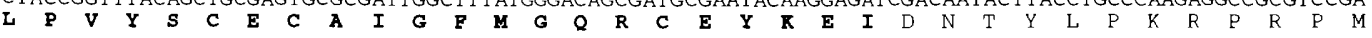

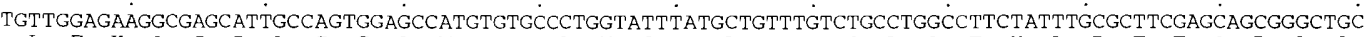

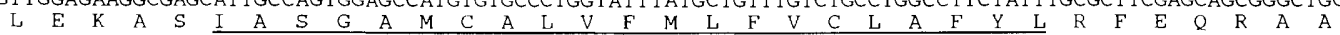
CAAGAAGGCC̈TACGAACTGGAGCAGGAACTGCAGCAGGAÄTACGACGATGACGACGGCCÄGTGCGAGTGCTTGCCGCAACCGGTGCTGTCCAGATGGCCAG

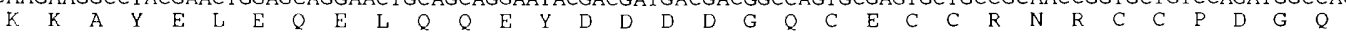

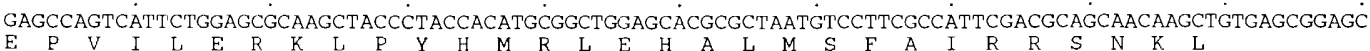

GAACTATGGÄAACTATAAAAAGATATAGAAAGTCGAATTTCGAATATGCĆTTGCCCAACÁCACAATTCTTTAACTGGGCTTTTTAGTCGATAGCTGATAACTC CTATTTACCTACCGCATGCTAAAGATCTGTTCACCCGATTCTATATAGAGATCTTGACTTTCTCTTACCÁAAAGTTACCCAGAAAGGGGGTTTTAAAGCC AGACAGCCTTGTATTACCCÄATTGACTATGAATTTTAATACCTAACGCTÁGCTATTTATTATTACTGCTÁACTGATATACGTATCACACÁCACAACGCGA்

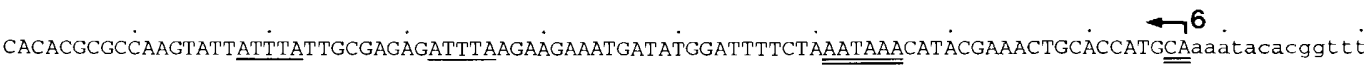
tttaatttaàggtgccggaàgtcaagatct

Figure 3. (See facing page for legend.) 
Transcripts hybridizing to the spi-coding region were seen throughout development, with peak expression in mid-embryogenesis, when the nervous system is being formed (Fig. 2C). Consistent with the previous finding that spi is maternally expressed (Mayer and NüssleinVolhard 1988), transcripts are seen in RNA from 0- to 1-hr embryos.

\section{Properties of the spi-coding region and the putative spi protein}

Sequence analysis of the various spi cDNAs and genomic DNA (Fig. 3) reveals a single long open reading frame, with two potential ATG initiation codons separated by 12 nucleotides. The sequence 5 ' to the first ATG codon in spi (TGTA) does not match the consensus sequence of the region 5' to a Drosophila translational start site $\| \mathrm{C} /$ A)AA(C/A)] (Cavener 1987), although the sequence flanking the second ATG (CACA) matches the consensus sequence fairly well. Thus, like other Drosophila genes recently examined (e.g., scabrous, Mlodzik et al. 1990; Serrate, Fleming et al. 1990), spi probably initiates translation at the second ATG codon. Termination of translation occurs with the codon TGA, producing a coding region of 690 nucleotides.

The spi gene encodes a potential protein of $26 \mathrm{kD}$ with a putative signal sequence, an EGF domain, and a potential transmembrane domain (Figs. 3 and $4 \mathrm{~A}, \mathrm{~B}$ ). There is a potential $\mathrm{N}$-linked glycosylation site at residue 70 (AsnIle-Thr), and between the EGF domain and the transmembrane domain there is a dibasic amino acid sequence, Lys-Arg, which could be a proteolytic cleavage site.

The most striking feature of the spi protein is the single EGF domain, which is homologous to the EGF domains in other members of the EGF family (Fig. 4C). The six cysteines are conserved, with correct spacing, and the other invariant residues are either conserved /as with Tyr/Phe-13, Leu-15, Gly-36, Tyr-37, Gly-39, and Arg-41; nomenclature follows EGF convention) or differ by conservative substitutions in spi (e.g., Leu-47 to Ile). Like vaccinia virus growth factor (VGF) and unlike transforming growth factor- $\alpha$ (TGF- $\alpha$ ) or EGF (Venkatesan et al. 1982; Derynck et al. 1985; Bell et al. 1986), the EGF domain in the spi-coding region is not interrupted by an intron.

\section{Phenotypic analysis of spi}

As described previously (Mayer and Nüsslein-Volhard 1988), embryos homozygous for spi show a partial fusion of denticle bands along the ventral midline, abnormal and incomplete formation of larval head structures, and displacement and/or reduction in specific cuticular sensory organs, such as the Keilin's organs. In addition to these epidermal defects, fusion of the anterior and posterior commissures (Klämbt et al. 1991; D. Smouse and
N. Perrimon, unpubl.) is observed in spi mutants. Because these phenotypes have been described previously, we have concentrated instead on analyzing the effect of spi mutations on the PNS and on muscle development.

The embryonic PNS in abdominal segments consists of three major clusters of sensory organs located at the dorsal, lateral, and ventral positions. In spi mutants, certain sensory organs are missing and there appears to be a ventral-dorsal gradient of severity of this missing sensory organ phenotype. The sensory organs of dorsal clusters in spi mutants appear to be quite normal both in number and in morphology (Fig. 5A,C,E,F). In the lateral clusters, spi mutants lack 2 of the 11 sensory organs found in wild-type embryos (Fig. 5B,D,E-J). The missing sensory organs are always two of the five lateral chordotonal organs, a phenotype shared by mutants of a subset of the spitz group genes: rho, $S$, and pnt (Bier et al. 1990).

A single precursor gives rise to all four cells required to form a chordotonal organ (Bodmer et al. 1989): a neuron, a scolopale cell that wraps around the dendrite of the neuron, and two support cells. These cells can be seen by marking all sensory organ cells with the enhancer trap line A37 (not shown) or by staining embryos with cell type-specific antibodies (Fig. 5A,B,E-H). The monoclonal antibody mAb44c11 labels neuronal nuclei (Bier et al. 1988) (Fig. 5A,B), anti-horseradish peroxidase (HRP) labels neuronal membranes and scolopales (Jan and Jan 1982; Bodmer et al. 1987) (Fig. 5E,F), and mAb21A6 labels the scolopale (Fig. 5G,H) (Zipursky et al. 1984). Results from immunocytochemical experiments with spi mutants indicate that all of the components of the two missing chordotonal organs are absent, suggesting that the spi mutation affects the precursors of the chordotonal organ.

The five lateral chordotonal organs have similar morphology, but they are not identical. The anterior-most chordotonal organ does not stain with mAb49C4, an antibody that stains the remaining four lateral chordotonal organs (Bodmer et al. 1987). Immunocy tochemical staining of spi mutants with mAb49C4 (Fig. 5I,J) showed that the anterior-most chordotonal organ is always one of the three remaining chordotonal organs.

In the ventral regions of spi embryos, the PNS phenotypes are the most severe and variable. In wild-type embryos, there are 19 sensory organs in the $\mathrm{V}$ and $\mathrm{V}^{\prime}$ clusters in the ventral region. The most commonly observed spi phenotype is that 5 of the 19 sensory organs are missing (Fig. 5B,D), although the number of missing sensory organs varies from segment to segment and from embryo to embryo (Fig. 5D). All three types of sensory organs (es organ, ch organ, and md neurons) are affected in spi mutants. An additional aspect of the mutant phenotype is that the locations of the $\mathrm{V}$ and $\mathrm{V}^{\prime}$ clusters in spi mutants are not as regular as in wild type.

In addition to alterations in the PNS, embryos mutant for spi have abnormal muscle development (Fig. 6). To describe the phenotype, we use the terminology of Bate (1990) (for a detailed diagram of muscle pattern, see Fig. 1 of Bate 1990). In normal embryos the body wall muscle pattern is well established by $13 \mathrm{hr}$ of embryogenesis. 


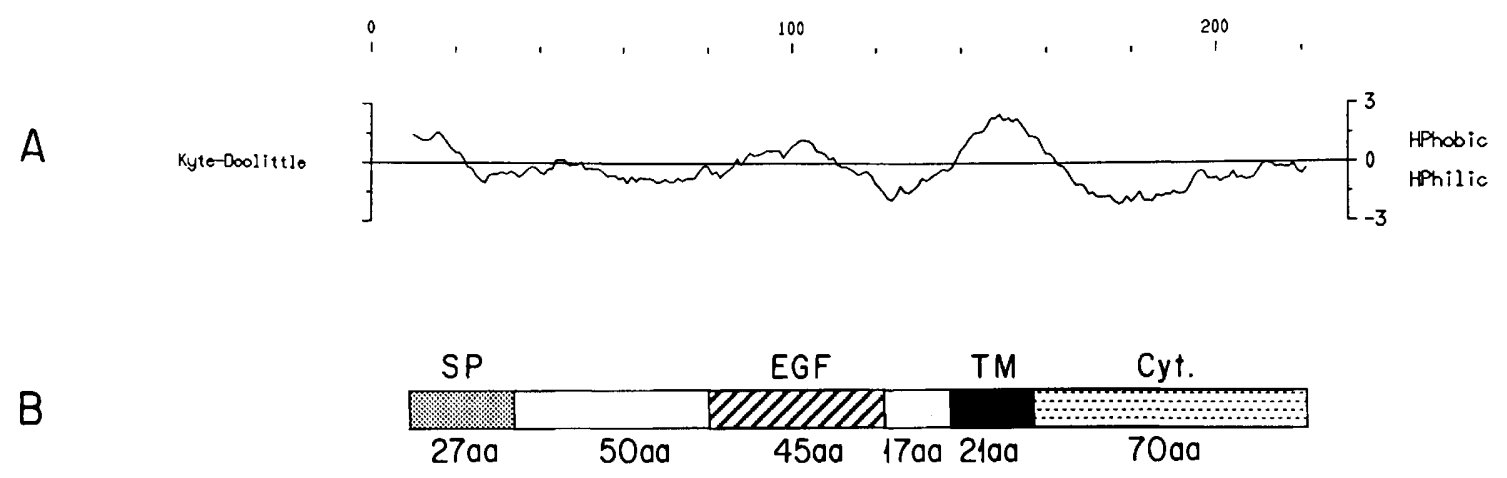

C

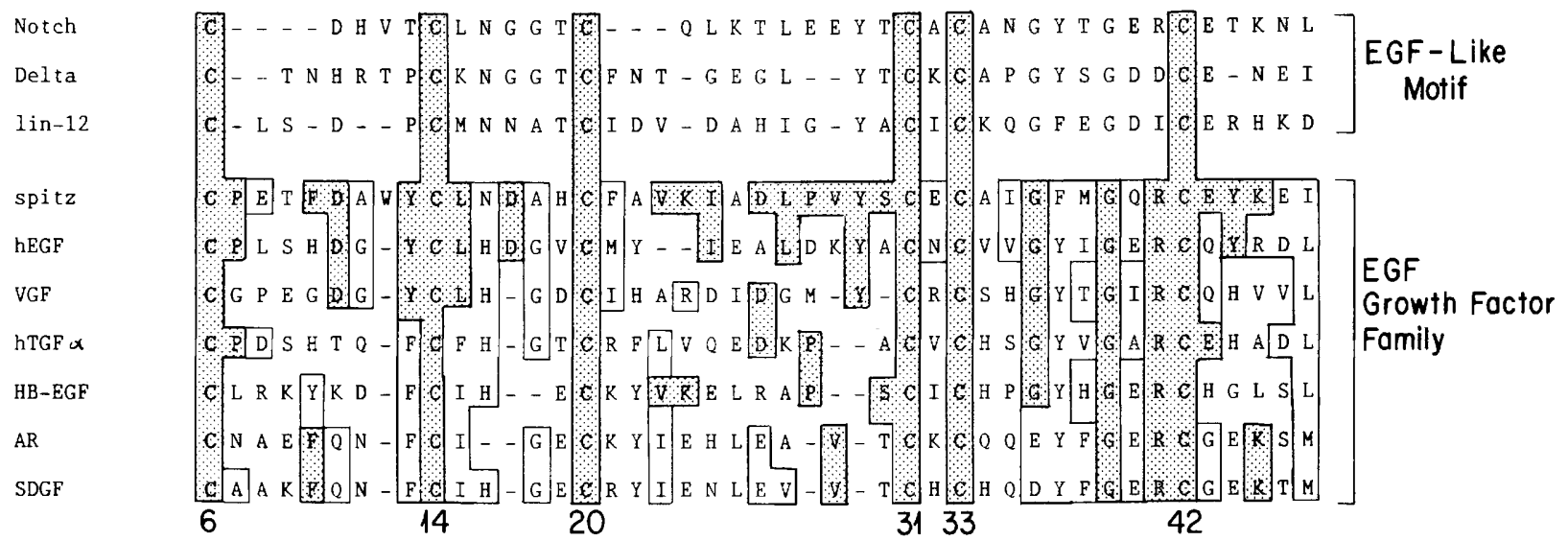

Figure 4. Analysis of the spi protein. $(A)$ Hydropathy profile of the predicted spi protein. The plot was generated using the algorithm of Kyte and Doolittle (1982), with the hydropathy window set at 19 to reduce the noise and emphasize the transmembrane domain. $(B)$ Schematic of the spi protein. The putative signal peptide (SP), EGF domain, transmembrane domain (TM), and cytoplasmic domain (Cyt.) are shown with respect to their location in the hydropathy profile diagramed above. Numbers below the boxes indicate the size, in amino acids, of each region. (C) Comparison of the EGF spi domain with the EGF-like motif in genes from Drosophila and Caenorhabditis elegans, and comparison of the spi EGF domain with the EGF domain in members of the EGF family. (Top) EGF-like motifs from Notch (Wharton et al. 1985), Delta (Vässin et al. 1987; Kopczynski et al. 1988), and lin-12 (Yochem et al. 1988); (bottom) the EGF domains from human EGF (hEGF; Bell et al. 1986), vaccinia virus growth factor (VGF; Brown et al. 1985), human TGF- $\alpha$ (hTGF; Derynck et al. 1984), heparin-binding factor that is EGF-like (HB-EGF; Higashiyama et al. 1991), amphiregulin (AR; Plowman et al. 1990), and schwannoma-derived growth factor (SDGF; Kimura et al. 1990). The cysteines are numbered as they appear in human EGF. The conserved cysteines are shown in shaded boxes for all of the sequences. Comparisons in the EGF family are made relative to the spi protein, with conserved residues shown in shaded boxes and semiconserved residues shown in open boxes. Determination of which residues to designate as semiconserved was made on the basis of the BESTFIT program from the Wisconsin Genetics Computer Group sequence analysis programs.

There are 30 muscle fibers per hemisegment in abdominal segments 2-7 (Crossley 1978; Hooper 1986; Bate 1990), which can be visualized by staining with mAb6D5 (Caudy et al. 1988). In spi mutants, the muscle pattern is altered primarily in two regions (data not shown): Several muscle fibers are consistently missing in the dorsolateral region (fibers 3, 4, 11, 19, and 20), and there are variable abnormalities in the number, shape, and attachment sites of the muscle fibers of the eight ventral oblique muscles $(14.1,14.2,15,16,17,26,27,29)$, such that it is difficult to identify individual muscle fibers (Fig. 6). In addition, near the somatic muscle layer in spi mutants there are a number of mAb6D5-positive cells that may represent myoblasts that failed to fuse with the muscle founder cells.

\section{Spatial expression of spi}

In situ analysis with single-stranded RNA probes indicated that spi transcript is expressed ubiquitously in all embryonic tissues, with enrichment in the procephalic region, ventral midline, mesodermal layers and, possibly, PNS cells (Fig. 7). Consistent with the in situ pattern, the $\beta$-galactosidase expression pattern of the enhancer trap insertion $s p i^{I D B^{7}}$ is fairly ubiquitous. The $\beta$-galactosidase expression becomes detectable at stage 6 when gastrulation begins (data not shown).

A polyclonal antibody against a $T_{7}-$ spi fusion protein (see Materials and methods) was used to determine the embryonic expression pattern of spi protein. Staining of whole-mount embryos with the affinity-purified spi an- 


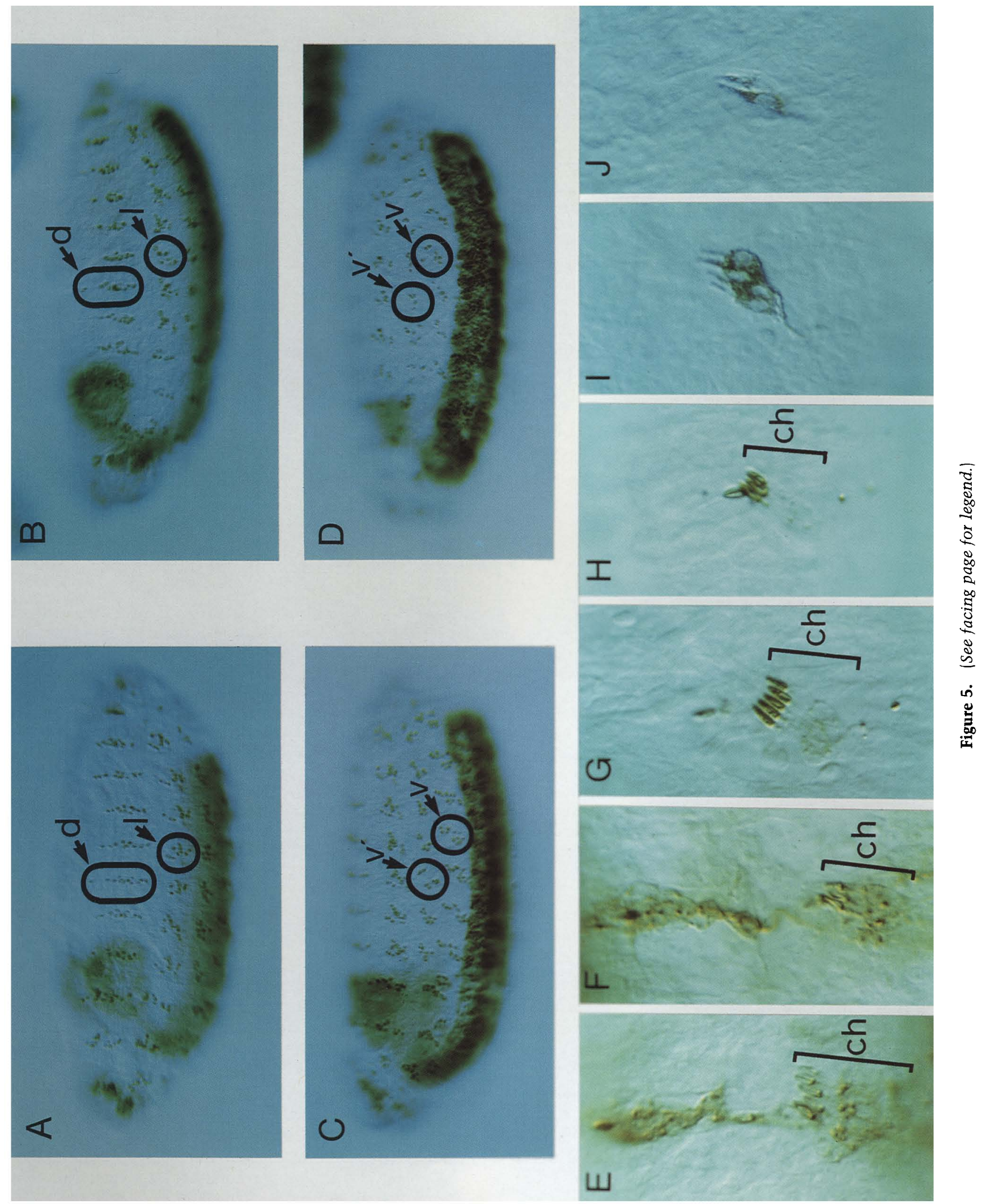




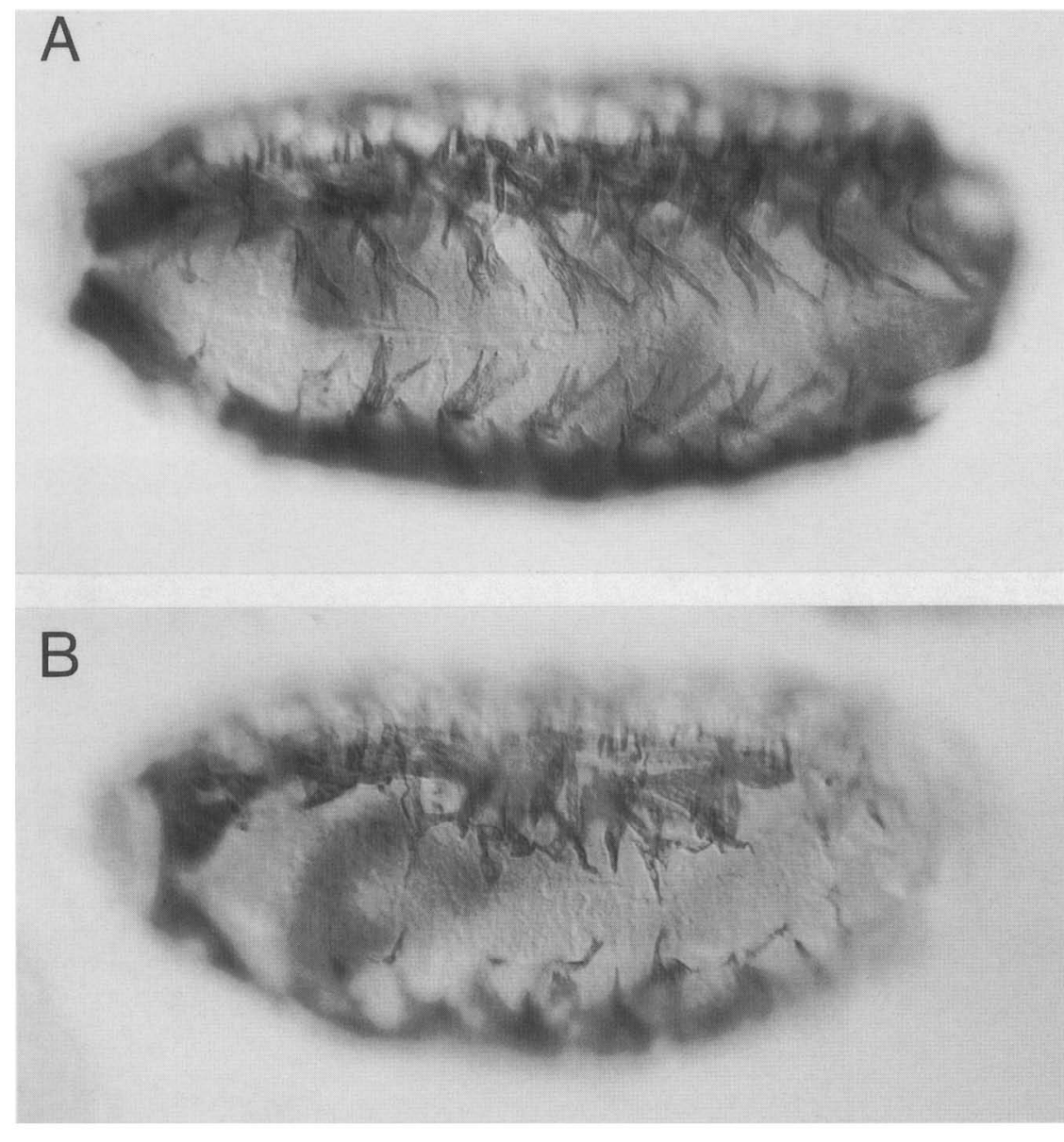

Figure 6. Muscle phenotype in spi mutant embryos. Ventral view of wild-type $(A)$ and spi $(B)$ mutant embryos stained with $\mathrm{mAb} 6 \mathrm{D} 5$, which labels muscle fibers. The ventral oblique muscles are present, but the number, shape, and attachment sites of those muscle fibers are quite variable. tibody showed ubiquitous expression of spi protein in the embryo, with slight enrichment in the mesoderm and in the ventral midline (data not shown), consistent with the results of RNA analysis and $\beta$-galactosidase expression.

\section{Discussion}

Using chromosomal walking and plasmid rescue of $s p i^{I D B 7}$, we have cloned the spi gene and we have rescued all aspects of the spi phenotype by transformation with a 12.5-kb genomic fragment. DNA sequence analysis of spi cDNAs predicts a putative $26-\mathrm{kD}$ transmembrane protein with a single EGF repeat, suggesting that spi protein may function as a ligand homologous to TGF- $\alpha$ or EGF. Analysis of RNA and protein distribution indicates that spi is expressed ubiquitously during embryogenesis, with slightly higher expression in certain tissues.

\section{The spi gene encodes a putative EGF-like growth factor}

The putative spi protein shows the greatest similarity to

Figure 5. PNS phenotype in spi mutant embryos. $(A-D)$ Reduction of peripheral neurons as revealed by staining with $\mathrm{mAb} 44 \mathrm{C} 11$, which labels all neuronal nuclei. $(A)$ Lateral view of a wild-type embryo. In the abdominal segments $2-7$, each dorsal cluster (d) contains 11 sensory neurons; (1) lateral. (B) Lateral view of a spi mutant. Notice that the dorsal clusters are normal, whereas the number of sensory neurons is reduced from 11 to 9 in the lateral clusters. $\langle C|$ Ventrolateral view of a wild-type embryo. In the abdominal segments, the ventral clusters $\left(\mathrm{V}\right.$ and $\left.\mathrm{V}^{\prime}\right)$ contain 19 sensory neurons. $(D)$ Ventrolateral view of a spi mutant. The number of sensory neurons in $\mathrm{V}$ and $\mathrm{V}^{\prime}$ clusters is typically reduced to 14 . The number and position of $\mathrm{V}$ and $\mathrm{V}^{\prime}$ sensory neurons are somewhat variable in spi mutants. $(E, F)$ Anti-HRP staining of the dorsal and lateral clusters of sensory neurons in the abdominal segments of a wild-type and a spi mutant embryo, respectively. Only three of the five lateral chordotonal organs (ch) are present in the mutant embryo. Chordotonal organs have scolopales, a structure that stains positive with both anti-HRP and mAb21A6 (cf. $G$ and $H$ ). (G,H) The mAb21A6-positive scolopales of the abdominal lateral chordotonal organs in wild-type and a spi mutant, respectively. $(I, J)$ The staining of a subset of chordotonal neurons with mAb49C4. $(I)$ Four of five of the lateral chordotonal neurons in the abdominal segment of a wild-type embryo are stained. (The anterior-most chordotonal neuron is not stained.) $(J)$ In spi mutant embryos, two of the three remaining lateral chordotonal neurons stain with mAb49C4, indicating that the anterior-most chordotonal neuron is not affected by spi mutations. 


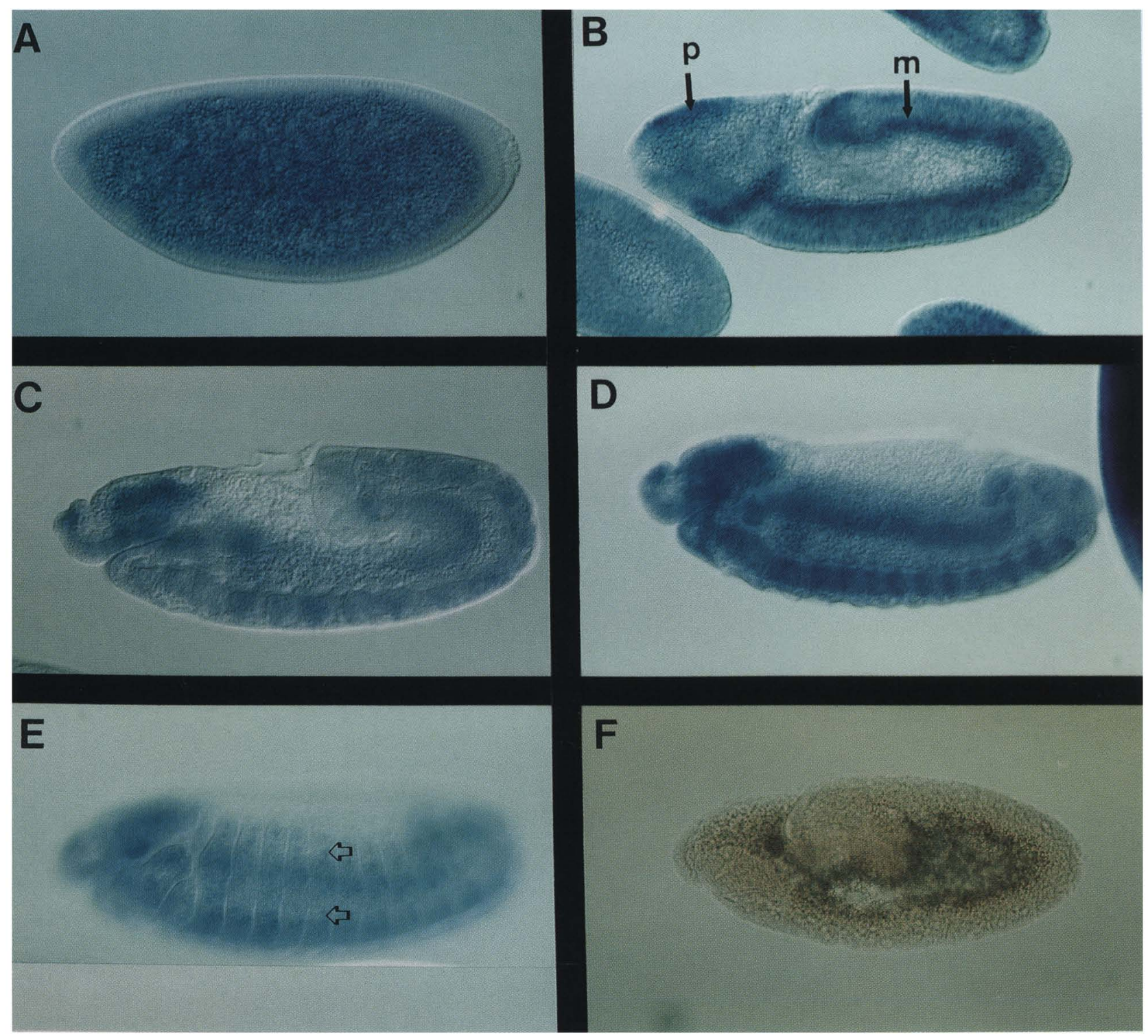

Figure 7. Embryonic expression pattern of spi. Whole-mount Drosophila embryos were hybridized with a digoxygenin c1-7 cDNA probe. For a description of the embryonic develomental stages, see Campos-Ortega and Hartenstein (1985). (A) At the cellular blastoderm stage, spi is expressed uniformly. $(B)$ At germ-band extension, spi transcripts are enriched in the mesodermal layer $(\mathrm{m})$ and the procephalic region $(\mathrm{p})$. (C) A germ-band-retracting embryo showing ubiquitous spi RNA. $(D, E)$ Fully retracted embryos showing enhanced expression of spi in the brain and ventral nerve cord $(D)$ and in cells that may give rise to the PNS (indicated by arrows in $E)$. $(F)$ No signal is detected when embryos are hybridized with a digoxygenin-labeled riboprobe corresponding to the sense strand. $(A-F)$ Anterior is to the left; dorsal is at the top.

proteins in the EGF family, with conservation of the EGF domain and other structural features characteristic of factors that are EGF-like. Like the EGF repeats in the Drosophila neurogenic genes Notch and Delta, the EGF domain in the predicted spi protein has absolute conservation of the 6 cysteines required to form three disulfide loops in EGF. Loop C, formed by a bond between cysteines 33 and 42 (Fig. 3C), is the most highly conserved region in the EGF repeat, with invariant residues Gly-36, Tyr-37, Gly-39, and Arg-41. The predicted spi protein differs from human EGF in loop $\mathrm{C}$ with a conservative
Tyr $\rightarrow$ Phe change at position 37; recent work has shown that this substitution in human EGF has little or no effect on biological activity of the protein (Engler et al. 1991). In addition, spi protein shows conservation of residues Tyr/Phe-13, Leu-15, and Arg-41, postulated to lie at the interface of the receptor and growth factor (for review, see Campbell et al. 1990) and has a conservative Leu $\rightarrow$ Ile change at position 47 . Thus, the single EGF domain in the predicted spi protein is homologous to the corresponding domain of human EGF. The overall structure of the spi protein is similar to that of the TGF- $\alpha$ 
precursor, which contains only one EGF domain, unlike the EGF precursor. TGF- $\alpha$ is structurally and biologically similar to EGF and binds with similar affinity to the EGF receptor (for review, see Massague 1990). It is interesting to note that TGF- $\alpha$ is active both as a membrane-bound protein and as a 50-amino-acid diffusible protein cleaved from the membrane-bound form (for review, see Massague 1990), raising the possibility that spi might not need to be cleaved to be biologically active.

\section{Potential function of the spi protein}

spi transcripts, although enriched in some tissues, have a fairly ubiquitous distribution. Because the predicted $s p i$ protein is structurally similar to an EGF-like factor, one model for spi function is that spi encodes a ubiquitously distributed ligand that interacts with spatially localized receptors, or molecules involved in its signal transduction. This model predicts that mutations in both spi and its receptor would have similar mutant phenotypes and that the receptor would be expressed in those tissues affected in mutant embryos. Obvious candidates for other proteins involved in the spi pathway are members of the spitz group, such as $S$, rho, and pnt. Of these, only rho has been characterized at the molecular level; rho encodes a putative transmembrane protein with three to seven membrane-spanning regions (Bier et al. 1990).

Although there are some differences in the fine details, $s p i$ and rho have similar phenotypes. Both spi and rho cause similar pattern defects in the embryonic ventral ectoderm (Fig. 4; Mayer and Nüsslein-Volhard 1988). The cuticular elements missing in these mutant embryos are derived from the same longitudinal strips of the blastoderm. The muscle phenotypes of the spi (Fig. 6) and rho mutants are also very similar. In both cases, the mutations affect primarily two groups of muscles: (1) Several muscles in the dorsolateral region are missing; and (2) the ventral oblique muscles have abnormal morphology and attachment sites. Finally, the CNS and PNS phenotypes are similar. With the CNS phenotype, Klämbt et al. (1991) noted that in both spi and rho mutant embryos, the fusion of anterior and posterior commissures results from the failure of specific glial cells to migrate and separate the anterior and posterior commissures. In the PNS, both mutations delete two of the five chordotonal organs in the lateral cluster (Fig. 5) and one of the two chordotonal organs in the ventral region. The spi phenotype is more severe than the rho phenotype in that additional sensory organs are missing in spi mutants. In both mutants the defect is probably at the level of sensory organ precursor formation.

Because the phenotypes of spi and rho are so similar, it is likely that these genes act in the same biochemical pathway. Since spi is ubiquitously distributed and $r h o$ is spatially localized to cells that require rho function, rho may be the receptor (or part of the receptor or a factor required for receptor-mediated signal transduction) for the spi product. Support for rho acting as a receptor derives from the complex expression pattern of $r h o$, which correlates well with tissues showing the mutant pheno- type. Such a model is plausible because the rho gene product is a putative integral membrane protein with several transmembrane domains (Bier et al. 1990). A prediction from this model, not yet tested, is that spi mutations should be non-cell-autonomous while the requirement for rho should be cell-autonomous.

\section{Relationships between DER and spi}

Because of the structural similarity of spi protein to a factor that is EGF-like, the most obvious candidate for a spi receptor is DER (Livneh et al. 1985). However, it is unlikely that $D E R$ is the sole receptor that confers $s p i$ specificity. The spatial distribution of $D E R$ covers a broader area than the regions that are altered in spi mutants, and the range of tissues affected in a DER mutant is greater than the range affected by spi (Zak et al. 1990). Nevertheless, there are some interesting correlations between $D E R$ and spi.

There is a phenotypic series of embryonic lethal faint little ball (flb) mutations of $D E R$, with weak $f l b$ mutations showing phenotypic similarities to spi mutations. Like $s p i$, the phenotype of weak $f l b$ mutations includes both cuticular abnormalities, with the most severe defects in the ventral regions, and CNS abnormalities. Immunohistochemical studies showed that $D E R$ protein appears to be restricted to a subset of glial cells in the ventral midline in retracted germ-band embryos (Zak et al. 1990). Further studies with cell-specific markers (Raz and Shilo 1992) have shown that the midline glial cells affected by the $f l b$ mutation include the midline glial cells that fail to migrate and separate the commissures in spi mutants (Klämbt et al. 1991). A CNS phenotype similar to that of spi, S, and rho embryos, with fusion of the anterior and posterior commissures, is seen in temperature-shift experiments with $f l b^{1 F 26}$ embryos (Raz and Shilo 1992). One explanation for the similarity of the $f 1 b$ and spi phenotypes in the CNS is that interaction of the spi ligand with $D E R$ on the surface of the midline glial cells stimulates the midline glial cells to migrate and separate the commissures.

If $D E R$ is the receptor for $s p i$, why do flb null mutations have a more severe phenotype than spi mutations? One possibility is that the null embryonic phenotype of $s p i$ has not been seen. Even if one of the characterized spi mutations is a null mutation, maternal protein is likely to be present in spi embryos. Previous work by Mayer and Nüsslein-Volhard (1988) demonstrated a maternal requirement for spi, showing that $s p i$ is cell lethal in germ-line mosaics. In addition to spi, other ligands for $D E R$ undoubtedly exist; the other developmental functions of DER (Price et al. 1989; Schejter and Shilo 1989) suggest the existence of multiple $D E R$ ligands. To produce a receptor for the spi ligand, the rho product might function together with $D E R$, perhaps to facilitate the ligand activation of the $D E R$ tyrosine kinase. Spatial regulation of this interaction would occur as a consequence of the localized expression of rho. Further genetic and biochemical tests of this model are in progress. 


\section{Growth factors as conserved developmental signals acting as positional cues}

A substantial body of recent experimental evidence supports the idea that growth factor-related molecules play key roles in the establishment of anteroposterior and dorsoventral polarity during early Xenopus embryogenesis (for a recent review, see Melton 1991). When added to animal cap explants in varying combinations, Xenopus growth factors related to transforming growth factor- $\beta$ (TGF- $\beta$ ) and basic fibroblast growth factor (bFGF) induce the formation of tissue types derived from different axial locations (Kimelman and Kirschner 1987; Smith 1987; Weeks and Melton 1987; Green and Smith 1990). The first evidence that growth factors might play similar roles in Drosophila development was obtained from analysis of the $d p p$ locus. $d p p$ plays a major organizing role in establishing dorsal tissue fates (Irish and Gelbart 1987) and encodes a protein that is related to the TGF- $\beta$ class of growth factors (Padgett et al. 1987). The role for growth factors in establishing the dorsal-ventral axis is expanded by the finding that an EGF/TGF- $\alpha$-like growth factor encoded by the spi gene is required in a ventrolateral strip of blastoderm cells. These cells correspond to the initial domain of $r$ ho expression (Bier et al. 1990 ) and are ventral to those requiring $d p p$ activity. It is tempting to speculate that graded levels of $d p p$ and $s p i$ activity might act to set up more precise positional values in the dorsal and ventrolateral regions, respectively. It is also possible that cells near the boundaries of the $d p p$ and ventrolateral domains are specified by combinations of $d p p$ and $s p i$ activity. It will be interesting to determine whether a spi homolog is present in vertebrates and whether EGF-type diffusible factors participate in dorsoventral axis formation during Xenopus development.

In Xenopus it appears that early patterning is initiated by the localized secretion of diffusible factors, which then activate various genes encoding transcription factors in restricted domains of the embryo. In contrast, early Drosophila embryonic patterning along both the anteroposterior and dorsoventral axis is based largely on cascades of localized transcription factors that diffuse short distances in the syncytial embryo. It is possible that the recent evolution of the syncytial blastoderm in long germ-band insects such as Drosophila has led to an elimination of some but not all of the dependence on diffusible factors. These diffusible factors may provide a mechanism to initiate patterning in cellularized embryos where transcription factors cannot directly diffuse from one cell to another. Thus, the apparent differences in the establishment of early patterning in Drosophila versus Xenopus may be superficial, reflecting the comparatively recent ability of transcription factors to diffuse directly in syncytial embryos.

\section{Materials and methods}

Drosophila stocks

Strains mutant for spi are listed in Table 1. Unless otherwise noted, the stocks were provided by the Bowling Green and In- diana stock centers. $D f(2 L) O D 12, D f(2 L) O D 21,1(2) E 142$, and $s p i^{O E 92}, s p i^{O D 7}$, and $s p i^{O D 24}$ were provided by D. Contamine (CNRS, Gif/Yvette, France). spi ${ }^{d p p 13}$ was provided by W. Gelbart (Biolabs, Harvard University, Cambridge, MA). The strain used for P-element-mediated germ-line transformation was $y \mathrm{w}$. Transformants were mapped and made homozygous by using Muller-6; In(2LR)Gla/SM5 and $w^{118} ; \mathrm{TM} 3, \mathrm{Sb} / \mathrm{Cx}^{D}$. For dysgenic crosses we used the strain y $w ; D 2.3, S b / T M 6$. Mutations and chromosome balancers are described in Lindsley and Grell (1968).

Stocks were maintained at $25^{\circ} \mathrm{C}$ on standard cornmeal/molasses/agar medium.

\section{Germ-line transformation}

The $12.5-\mathrm{kb}$ BamHI fragment from phage $\mathrm{R}_{37}$ was subcloned into P-element vector pCaSpeR2 (Pirrotta 1988) to construct Bam-8. Note that the proximal BamHI site in phage $R_{37}$ was created fortuitously in the EMBL3 library construction and does not correspond to a genomic site. The Bam-8 plasmid was digested with NotI and electrophoresed, and the larger of the two resulting restriction fragments was gel purified and religated to generate plasmid Not-3. Following standard protocols (Spradling 1986), embryos were injected with a mixture of recombinant plasmid $(800 \mathrm{mg} / \mathrm{ml})$ and helper plasmid $(200 \mathrm{mg} / \mathrm{ml})$. The helper plasmid used was pD2-3 (Laski et al. 1986).

\section{Isolation and hybridization analysis of genomic DNA}

Genomic DNA from $D f(2 L) V A 17 / C y O$ flies was cloned into l-Dash (Stratagene) by use of the Gigapack packaging extract according to the manufacturer's specifications (Stratagene). A second library was made under identical conditions with Oregon- $R$ wild-type flies. The $D f(2 L) V A 17$ library was screened with plasmid p1022 (Gilbert et al. 1984). The phage hybridizing strongly to the probe were isolated, and a phage containing DNA spanning the $D f(2 L) V A 17$ breakpoint was identified by restriction analysis. Restriction fragments from this phage were used to initiate a phage walk from the wild-type l-Dash library, and the walk was extended by use of both this library and an EMBL3 library (Blackman et al. 1987). In Figure 1, phage 5-2, 4C, and $\mathrm{R}_{37}$ are from the EMBL3 library, and the remaining phage are from the l-Dash library.

Plasmid rescue of the P-element insertion in $s p i^{I D B 7}$ was carried out according to the protocol of Wilson et al. (1989).

For Southern analysis, 5-10 $\mu$ g of genomic DNA was digested overnight, electrophoresed, and blotted according to standard protocols (Maniatis et al. 1982). DNA hybridization probes were radiolabeled by the random primer method (Feinberg and Vogelstein 1983).

\section{Isolation of $c D N A$ s and RNA analysis}

The 1.3-kb EcoRI restriction fragment was used as a hybridization probe to isolate phage from a 0- to 4-hr embryonic cDNA library cloned into $\lambda$ gt 10 (Frigerio et al. 1986). Twelve phage were isolated, and four were analyzed in detail. A 1.1-kb EcoRIPst I derivative of the $1.3-\mathrm{kb} E$ coRI fragment was used to isolate phage from a 9- to 12-hr embryonic cDNA library cloned into igt 11 (Zinn et al. 1988). Three phage were isolated, and one was analyzed in detail. Each of the five phage analyzed appeared to contain a single EcoRI fragment, which was gel-purified and subcloned into $\mathrm{pBSK}^{+}$for sequencing.

Total RNA was isolated from staged embryos, larvae, and pupae by the guanidinium/cesium chloride method (Maniatis et al. 1982) and affinity purified on oligo(dT)-cellulose (Collab- 
orative Research). Northern blot analysis was performed by using standard methods (Maniatis et al. 1982). DNA hybridization probes were radiolabeled by the random primer method (Feinberg and Vogelstein 1983), and single-stranded RNA probes were made from fragments cloned into $\mathrm{pBSK}^{+}$vectors, according to the method of Melton et al. (1984).

\section{DNA sequencing and computer analysis}

DNA sequencing (Sanger et al. 1977) was carried out on doublestranded plasmids by use of $T_{7}$ polymerase (Pharmacia). Templates were made both by subcloning different restriction fragments into $\mathrm{pBSK}^{+}$(Stratagene) and by generating nested exonuclease III deletions of subcloned fragments with the Erase-aBase system (Promega). Specific primers were synthesized to extend the sequence on a given strand. The sequence of the genomic DNA was determined on both strands.

DNA sequence analysis utilized the Wisconsin Genetics Computer Group sequence analysis package and the GenBank and GenPept data bases. Optimal amino acid alignment between two sequences was made by using the BESTFIT program (Devereux et al. 1984). Homology searches utilized the FASTA program (Pearson and Lipman 1988), and the hydropathy profile was generated using the Kyte and Doolittle (1982) algorithm.

\section{Production of polyclonal antibodies against}

\section{$T_{T}$-spi fusion protein}

The SpeI-EcoRI fragment from spi cDNA cl-7 was ligated into the bacterial $\mathrm{T}_{7}$ expression vector pAR3040 and transformed into the BL21D3 strain (Studier and Moffatt 1986). After induction with IPTG, inclusion body preparations were electrophoresed with SDS-PAGE (Harlow and Lane 1988) and the protein band corresponding to the $T_{T}-s p i$ fusion was excised and injected into rats for production of polyclonal antisera. Positive sera were purified according to a standard protocol (Harlow and Lane 1988) with an antigen-coupled affinity column made by coupling activated agrose beads (Bio-Rad) to soluble fractions of inclusion body preparations from strains containing either the $\mathrm{T}_{7}$ vector alone (nonspecific column) or the $\mathrm{T}_{7}-$ spi construct (specific column). The antigen-bound antibodies were eluted at $\mathrm{pH} 2.5$ and neutralized to $\mathrm{pH} 8.0$ according to Harlow and Lane (1988).

\section{In situ hybridization}

In situ hybridizations were done by use of nonradioactive digoxygenin-labeled probes as described by Tautz and Pfeifle (1989). The DNA probes were made from gel-purified 1.6-kb fragment of the spi c1-7 cDNA clone. Strand-specific RNA digoxygenin probes were generated by in vitro transcription as described by Melton et al. (1984). Both DNA and RNA probes were made by using labeling kits from Boehringer Mannheim.

\section{Analysis of embryos}

Cuticle preparations were done as described by van der Meer (1977). To examine the CNSs of mutant embryos, we used an anti-HRP polyclonal antibody (Cappel) and mAbBP102 (an antibody that stains CNS axons, from A. Bieber and C.S. Goodman, University of California, Berkeley, CA). The lacZ expression pattern of $s p i^{I D B 7}$ was determined by use of a mouse anti$\beta$-galactosidase primary antibody (from Promega).

To examine the PNS of spi embryos, we used a variety of cell markers: anti-HRP / which stains neuronal membrane as well as scolopale cells of the chordotonal organs| and three mouse monoclonal antibodies: mAb44C11, which labels all neuronal nuclei; mAb21A6, which labels the scolopale and the tip of dendrites of external sensory organs; and mAb49C4, which stains a subset of chordotonal neurons. The protocol for immunohistochemical staining with those antibodies is described in Bodmer et al. (1987).

Muscle fibers were visualized by staining with mAb6D5 (Caudy et al. 1988).

\section{Acknowledgments}

We thank D. Contamine, W. Gelbart, T.R.F. Wright, and the Indiana and Bowling Green centers for Drosophila stocks; D. Contamine, L. Ambrosio, and J. Hirsh for plasmids; K. Zinn, W. Gelbart, and M. Noll for cDNA or genomic libraries; A. Bieber and C. S. Goodman for the BP102 antibody; L. Perkins for comments on the manuscript; and D. Contamine and D. Smouse for communication of unpublished data. B.J.R. was the recipient of a National Institutes of Health postdoctoral fellowship and a Charles King/Medical Foundation fellowship. This work was supported by the Howard Hughes Medical Institute.

The publication costs of this article were defrayed in part by payment of page charges. This article must therefore be hereby marked "advertisement" in accordance with 18 USC section 1734 solely to indicate this fact.

\section{References}

Bate, M. 1990. The embryonic development of larval muscles of Drosophila. Development 110: 791-804.

Bell, G.I., N.M. Fong, M.M. Stempien, M.A. Wormsted, D. Caput, L. Ku, M.S. Urdea, L.B. Rall, and R. Sanchez-Pescador. 1986. Human epidermal growth factor precursor: cDNA sequence, expression in vitro and gene organization. Nucleic Acids Res. 14: 8427-8446.

Bier, E., L.Y. Jan, and Y.N. Jan. 1990. rhomboid, a gene required for dorsoventral axis establishment and peripheral nervous system development in Drosophila melanogaster. Genes Dev. 4: 190-203.

Bier, E., L. Ackerman, S. Barbel, L.Y. Jan, and Y.N. Jan. 1988. Identification and characterization of a neuron-specific nuclear antigen in Drosophila. Science 232: 485-487.

Bier, E., H. Vässin, S. Shephard, K. Lee, K. McCall, S. Barbel, L. Ackerman, R. Carretto, T. Uemura, E. Grell, L.Y. Jan, and Y.N. Jan. 1989. Searching for pattern and mutation in the Drosophila genome with a P-lacZ vector. Genes \& Dev. 3: 1273-1287.

Blackman, R.K., R. Grimaila, M.M.D. Koehler, and W.M. Gelbart. 1987. Mobilization of hobo elements residing within the decapentaplegic gene complex: Suggestion of a new hybrid dysgenesis system in Drosophila melanogaster. Cell 49: 497-505.

Bodmer, R., S. Shepherd, J. Jack, L.Y. Jan, and Y.N. Jan. 1987. Transformation of sensory organs by mutations of the cut locus of D. melanogaster. Cell 51: 293-307.

Bodmer, R., R. Carretto, and Y.N. Jan. 1989. Neurogenesis of the peripheral nervous system in Drosophila melanogaster embryos: DNA replication patterns and cell lineages. Neuron 3: $21-32$

Brown, J.P., D.R. Twardzik, H. Marquardt, and G.J. Todaro. 1985. Vaccinia virus encodes a polypeptide homologous to epidermal growth factor and transforming growth factor. $\mathrm{Na}$ ture 313: 491-492.

Campbell, I.D., M. Baron, R.M. Cooke, T.J. Dudgeon, A. Fallon, T.S. Harvey, and M.J. Tappin. 1990. Structure-function rela- 
tionships in epidermal growth factor (EGF) and transforming growth factor-alpha (TGF- $\alpha$ ). Biochem. Pharmacol. 40: 3540.

Campos-Ortega, J.A. and V. Hartenstein. 1985. The embryonic development of Drosophila melanogaster. Springer Verlag, New York.

Caudy, M., E. Grell, C. Dambly-Chaudiere, A. Ghysen, L.Y. Jan, and Y.N. Jan. 1988. The maternal sex determination gene daughterless has zygotic activity necessary for the formation of peripheral neurons in Drosophila. Genes \& Dev. 2: 843852.

Cavener, D.R. 1987. Comparision of the consensus sequence flanking translational start sites in Drosophila and vertebrates. Nucleic Acids Res. 15: 1353-1361.

Contamine, D., A.-M. Petitjean, and M. Ashburner. 1989. Genetic resistance to viral infection: The molecular cloning of a Drosophila gene that restricts infection by the rhabdovirus sigma. Genetics 123: 525-533.

Crews, S., I. Thomas, and C.S. Goodman. 1988. The Drosophila single-minded gene encodes a nuclear protein with sequence similarity to the per gene product. Cell 52: 143-151.

Crossley, A.C. 1978. The morphology and development of the Drosophila muscular system. In The genetics and biology of Drosophila (ed. M. Ashburner and T.R.F. Wright), vol. 2b, pp. 499-560. Academic Press, New York.

Derynck, R., A.B. Roberts, M.E. Winkler, E.Y. Chen, and D.V. Goeddel. 1984. Human transforming growth factor- $\alpha$ : Precursor structure and expression in E. coli. Cell 38: 287-297.

Derynck, R., A.B. Roberts, D.H. Eaton, M.E. Winkler, and D.V. Goeddel. 1985. Human transforming growth factor- $\alpha$ : Precursor structure, gene structure, and heterologous expression. Cancer Cells 3: 79-86.

Devereaux, J., P. Haeberli, and O. Smithies. 1984. A comprehensive set of sequence analysis programs for the VAX. $\mathrm{Nu}$ cleic Acids Res. 12: 387-391.

Doyle, H.J., K. Harding, T. Hoey, and M. Levine. 1986. Transcripts encoded by a homeo box gene are restricted to dorsal tissues of Drosophila embryos. Nature 323: 76-79.

Engler, D.A., M.R. Hauser, J.S. Cook, and S.K. Niyogi. 1991. Aromaticity at position 37 in human epidermal growth factor is not obligatory for activity. Mol. Cell. Biol. 11: 24252431.

Feinberg, A.P. and B. Vogelstein. 1983. A technique for radiolabeling DNA restriction endonuclease fragments to high specific activity. Anal. Biochem. 132: 6-13.

Fleming, R.J., T.N. Scottgalle, R.J. Diedrich, and S. ArtavanisTsakonas. 1990. The gene Serrate encodes a putative EGFlike transmembrane protein essential for proper ectodermal development in Drosophila melanogaster. Genes \& Dev. 4: 2188-2201.

Frigerio, G., M. Burri, D. Bopp, S. Baumgartner, and M. Noll. 1986. Structure of the segmentation gene paired and the Drosophila PRD gene set as part of a gene network. Cell 47: 735-746.

Gilbert, D., J. Hirsh, and T.R.F. Wright. 1984. Molecular mapping of a gene cluster flanking the Drosophila dopa decarboxylase gene. Genetics 106: 679-694.

Green, J.B.A. and J.C. Smith. 1990. Graded change in dose of a Xenopus activin A homologue elicit stepwise transitions in embryonic cell fate. Nature 347: 391-394.

Harlow, E. and D. Lane. 1988. Antibodies: A laboratory manual. Cold Spring Harbor Laboratory, Cold Spring Harbor, New York.

Higashiyama, S., J.A. Abraham, J. Miller, J.C. Fiddes, and M. Klagsbrun. 1991. A heparin-binding growth factor secreted by macrophage-like cells that is related to EGF. Science
251: 936-939.

Hooper, J.E. 1986. Homeotic gene function in the muscles of Drosophila larvae. EMBO I. 5: 2321-2329.

Irish, V.F. and W.M. Gelbart. 1987. The decapentaplegic gene is required for dorsal-ventral patterning of the Drosophila embryo. Genes \& Dev. 1: 868-879.

Jan, L.Y. and Y.N. Jan. 1982. Antibodies to horseradish peroxidase as specific neuronal markers in Drosophila and grasshopper embryos. Proc. Natl. Acad. Sci. 70: 2700-2704.

Jan, Y.N., R. Bodmer, A. Ghysen, C. Dambly-Chaudiere, and L.Y. Jan. 1986. Mutations affecting the peripheral nervous system in Drosophila embryos. Proceedings of the UCLA Symposium for Molecular Entomology. I. Cell. Biochem. 45-56.

Karess, R.E. and G.M. Rubin. 1984. Analysis of P transposable element functions in Drosophila. Cell 38: 135-146.

Kimelman, D. and M. Kirschner. 1987. Synergistic induction of meoderm by FGF and TGF- $\beta$ and the identification of an mRNA coding for FGF in early Xenopus embryo. Cell 51: 869-877.

Kimura, H., W.H. Fischer, and D. Schubert. 1990. Structure, expression and function of a schwannoma-derived growth factor. Nature 348: 257-260.

Klämbt, C., J.R. Jacobs, and C.S. Goodman. 1991. The midline of the Drosophila central nervous system: A model for the genetic analysis of cell fate, cell migration, and growth cone guidance. Cell 64: 801-815.

Kopczynski, C.C., A.K. Alton, K. Fechtel, P.J. Kooh, and M.A.T. Muskavitch. 1988. Delta, a Drosophila neurogenic gene, is transcriptionally complex and encodes a protein related to blood coagulation factors and epidermal growth factor of vertebrates. Genes \& Dev. 2: 1723-1735.

Kruys, V., O. Marinx, G. Shaw, J. Deschamps, and G. Huez. 1989. Translation blockade imposed by cytokine-derived UA-rich sequences. Science 245: 852-854.

Kyte, J. and R.F. Doolittle. 1982. A simple method for displaying the hydropathic character of a protein. J. Mol. Biol. 157: 105132.

Laski, F.A., D.C. Rio, and G.M. Rubin. 1986. Tissue specificity of Drosophila $P$ element transposition is regulated at the level of mRNA splicing. Cell 44: 7-19.

Leptin, G. and G. Grunewald. 1990. Cell shape changes during gastrulation in Drosophila. Development 110: 73-84.

Lindsley, D. and E.H. Grell. 1968. Genetic variations of Drosophila melanogaster. Carnegie Inst. Washington Publ. 627.

Lindsley, D. and G. Zimm. 1985. The genome of Drosophila melanogaster. Part 1: Genes A-K. Dros. Inf. Serv. 62.

- 1986. The genome of Drosophila melanogaster. Part 3: Lethals, maps. Dros. Inf. Serv. 64.

Livneh, E., L. Glazer, D. Segal, J. Schlessinger, and B.-Z. Shilo. 1985. The Drosophila EGF receptor gene homolog: Conservation of both hormone binding and kinase domains. Cell 40: $599-607$.

Maniatis, T., E.F. Fritsch, and J. Sambrook. 1982. Molecular cloning: A laboratory manual. Cold Spring Harbor Laboratory, Cold Spring Harbor, New York.

Massague, J. 1990. Transforming growth factor- $\alpha$. I. Biol. Chem. 265: 21393-21396.

Mayer, U. and C. Nüsslein-Volhard. 1988. A group of genes required for pattern formation in the ventral ectoderm of the Drosophila embryo. Genes \& Dev. 2: 1496-1511.

Melton, D.A. 1991. Pattern formation during animal development. Science 252: 234-24l.

Melton, D.A., P.A. Krieg, M.R. Rebaglialti, T. Maniatis, K. Zinn, and M.R. Green. 1984. Efficient in vitro synthesis of biologically active RNA and RNA hybridization probes from plas- 
mids containing a bacteriophage SP6 promoter. Nucleic Acids Res. 12: 7035-7056.

Mlodzik, M., N.E. Baker, and G.M. Rubin. 1990. Isolation and expression of scabrous, a gene regulating neurogenesis in Drosophila. Genes \&) Dev. 4: 1848-1861.

Mount, S. 1982. A catalogue of splice junction sequences. $\mathrm{Nu}$ cleic Acids Res. 10: 459-472.

Nüsslein-Volhard, C., E. Wieshaus, and H. Kluding. 1984. Mutations affecting the pattern of the larval cuticle in Drosophila melanogaster. I. Zygotic loci on the second chromosome. Wilhelm Roux's Arch. Dev. Biol. 183: 267-282.

Padgett, R.W., R.D. St. Johnston, and W.M. Gelbart. 1987. A transcript from a Drosophila pattern gene predicts a protein homologous to the transforming growth factor- $\beta$ family. $\mathrm{Na}$ ture 325: 81-84.

Pearson, W.R. and D.J. Lipman. 1988. Improved tools for biological sequence comparison. Proc. Natl. Acad. Sci. 85: 2444-2448.

Pirrotta, V. 1988. Vectors for P-mediated transformation in Drosophila. In Vectors: A survey of molecular cloning vectors and their uses (ed. R.L. Rodriguez and D.T. Denhardt), pp. 437-456. Butterworths, Boston, MA

Plowman, G.D., J.M. Green, V.L. McDonald, M.G. Neubauer, C.M. Disteche, G.J. Todaro, and M. Shoyab. 1990. The amphiregulin gene encodes a novel epidermal growth factorrelated protein with tumor-inhibitory activity. Mol. Cell. Biol. 10: 1969-1981.

Price, J.V., R.J. Clifford, and T. Schupbach. 1989. The maternal ventralizing locus torpedo is allelic to faint little ball, an embryonic lethal, and encodes the Drosophila EGF receptor homolog. Cell 56: 1085-1092.

Proudfoot, N.J. and G.G. Brownlee. 1976. 3' Non-coding region sequences in eukaryotic mRNA. Nature 263: 211-214.

Raz, E. and B.-Z. Shilo. 1992. Dissection of the faint little ball $(f l b)$ phenotype: Determination of the development of the Drosophila central nervous system by early interactions in the ectoderm. Development 114: 113-123.

St. Johnston, R.D. and W.M. Gelbart. 1987. Decapentaplegic transcripts are localized along the dorsal-ventral axis of the Drosophila embryos. EMBO f. 6: 2785-2791.

Sanger, F., S. Nicklen, and A.R. Coulson. 1977. DNA sequencing with chain termination inhibitors. Proc. Natl. Acad. Sci. 74: 5463-5467.

Scheiter, E.D. and B.-Z. Shilo. 1989. The Drosophila EFG receptor homolog (DER) gene is allelic to faint little ball, a locus essential for embryonic development. Cell 56: 1093-1104.

Shaw, G. and R. Kamen. 1986. A conserved AU sequence from the 3' untranslated region of GM-CSF mRNA mediates selective mRNA degradation. Cell 46: 659-667.

Smith, J.C. 1987. A mesoderm-inducing factor is produced by Xenopus cell line. Development 99: 3-14.

Spradling, A.C. 1986. P element-mediated transformation. In Drosophila: A practical approach (ed. D.B. Roberts), pp. 175197. IRL Press, Oxford, England.

Stein, D., S. Roth, E. Vogelsang, and C. Nüsslein-Volhard. 1991. The polarity of the Drosophila embryo is defined by an extracellular signal. Cell 65: 725-735.

Steward, R. 1987. Dorsal, an embryonic polarity gene in Drosophila, is homologous to the vertebrate proto-oncogene, c-rel. Science 238: 692-694.

Studier, F.W. and B.A. Moffatt. 1986. Use of bacteriophage T7 RNA polymerase to direct selective high-level expression of cloned genes. J. Mol. Biol. 189: 113-130.

Tautz, D. and C. Pfeifle. 1989. A nonradioactive in situ hybridization method for the localization of specific RNAs in Drosophila embryos reveals a translational control of the segmentation gene hunchback. Chromosoma 98: 81-85.

Thomas, J., S. Crews, and C.S. Goodman. 1988. Molecular genetics of the single-minded locus: A gene involved in the development of the Drosophila nervous system. Cell 52: 133-141.

van der Meer, J. 1977. Optical clean and permanent whole mount preparations for phase contrast microscopy of cuticular structures of insect larvae. Dros. Inf. Serv. 52: 160.

Vässin, H., K.A. Bremer, E. Knust, and J.A. Campos-Ortega. 1987. The neurogenic locus Delta of Drosophila melanogaster is expressed in neurogenic territories and encodes a putative transmembrane protein with EGF-like repeats. EMBO I. 6: 3431-3440.

Venkatesan, S., A. Gershowitz, and B. Moss. 1982. Complete nucleotide sequences of two adjacent early vaccinia virus genes located within the inverted terminal repetition. $J$. Virol. 44: 637-646.

von Heijne, G. 1983. Patterns of amino acids near signal-sequence cleavage sites. Eur. J. Biochem. 133: 17-21.

Weeks, D.L. and D.A. Melton. 1987. A maternal mRNA localized to the vegetal hemisphere in Xenopus eggs codes for a growth factor related to TGF- $\beta$. Cell 51: 861-867.

Wharton, K.A., K.M. Johansen, T. Xu, and S. Artavanis-Tsakonas. 1985. Nucleotide sequence from the neurogenic locus Notch implies a gene product that shares homology with proteins containing EGF-like repeats. Cell 43: 567-581.

Wilson, C., R.K. Pearson, H.J. Bellen, C.J. O'Kane, U. Grossniklaus, and W.J. Gehring. 1989. P-element-mediated enhancer detection: An efficient method for isolating and characterizing developmentally regulated genes in Drosophila. Genes \& Dev. 3: 1301-1313.

Wright, T.R.F., R.B. Hodgetts, and A.F. Sherald. 1976. The genetics of dopa decarboxylase in Drosophila melanogaster. I. Isolation and characterization of deficiencies that deplete the dopa-decarboxylase-dosage-sensitive region and the $\alpha$-methyl-dopa hypersensitive locus. Genetics 84: 267-285.

Wright, T.R.F., W. Beerman, J.L. Marsh, C.P. Bishop, R. Steward, B.C. Black, A.D. Gomsett, and E.Y. Wright. 1981. The genetics of dopa decarboxylase in Drosophila melanogaster. IV. The genetics and cytology of the 37B10-37D1 region. Chromosoma 83: 45-58.

Yochem, J., K. Weston, and I. Greenwald. 1988. The Caenorhabditis elegans lin-12 gene encodes a transmembrane protein with overall similarity to Drosophila Notch. Nature 335: 547-550.

Zak, N.B., R.J. Wides, E.D. Schejter, E. Raz, and B.-Z. Shilo. 1990. Localization of the DER/flb protein in embryos: Implications on the faint little ball lethal phenotype. Development 109: 865-874.

Zinn, K., L. McAllister, and C.S. Goodman. 1988. Sequence analysis and neuronal expression of fasciclin I in grasshopper and Drosophila. Cell 53: 577-587.

Zipursky, S.L., T.R. Venkatesh, D.B. Teplow, and S. Benzer. 1984. Neuronal development in Drosophila retina: Monoclonal antibodies as molecular probes. Cell 36: 15-26. 


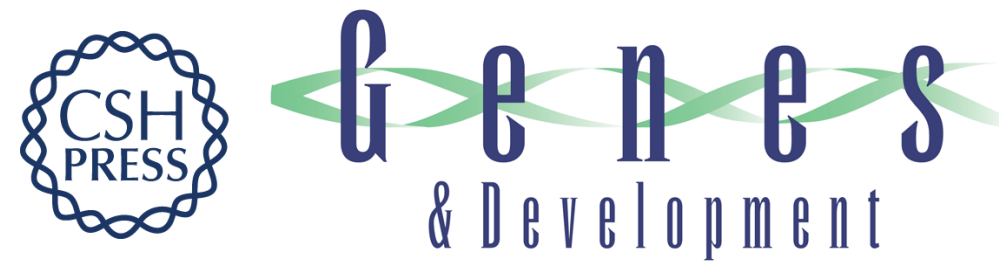

\section{The Drosophila spitz gene encodes a putative EGF-like growth factor involved in dorsal-ventral axis formation and neurogenesis.}

B J Rutledge, K Zhang, E Bier, et al.

Genes Dev. 1992, 6:

Access the most recent version at doi:10.1101/gad.6.8.1503

References This article cites 74 articles, 27 of which can be accessed free at: http://genesdev.cshlp.org/content/6/8/1503.full.html\#ref-list-1

License

Email Alerting

Service

Receive free email alerts when new articles cite this article - sign up in the box at the top right corner of the article or click here.

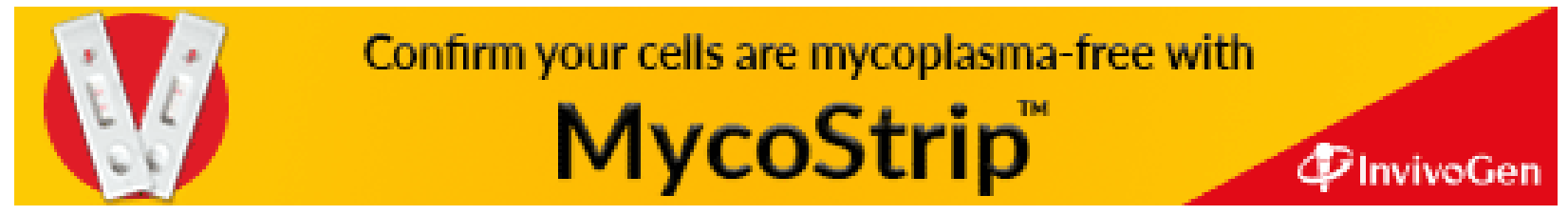

